\title{
Analisis Keterbacaan Teks Bahasa Inggris dalam Buku Ajar Wajib di Sekolah Menengah Pertama dengan Menggunakan Formula Flesch
}

\author{
Rita Karmila Sari \\ Program Studi Informatika \\ Universitas Indraprasta PGRI \\ Email: karmilasari_rita@yahoo.com
}

\begin{abstract}
ABSTRAK
Penelitian ini menganalisis mengenai keterbacaan teks dalam buku ajar wajib di sekolah menengah pertama yang berjudul English in Fokus Grade VII, VIII, dan IX terbitan Pusat perbukuan Departemen Pendidikan Nasional. Tujuan penelitian ini adalah melihat kesesuaian teks dengan tingkat pemelajar yang dituju. Teks dianalisis dengan menggunakan Formula Flesch. Formula ini memprediksi kesulitan teks dengan menghitung jumlah kata dan silabel dalam kalimat yang terdapat dalam teks yang dianalisis. Hasil analisis menyatakan bahwa hanya teks dalam buku English in Fokus Grade VII yang sesuai dengan tingkat pemelajarnya. Sedangkan teks yang terdapat dalam Buku English in Fokus Grade VIII dan IX dianggap terlalu mudah. Pada Buku English in Fokus Grade VIII hanya 3 teks yang sesuai dengan tingkatan pemelajar dari 8 teks yang dianalisis. Pada buku English in Fokus Grade IX, hanya 1 teks yang sesuai dengan pemelajarnya. Oleh sebab itu, penting bagi pengajar untuk menganalisis kembali teks yang terdapat dalam buku ajar yang mereka gunakan.
\end{abstract}

\section{Kata Kunci: Keterbacaan teks, Formula Flesch, buku ajar}

\section{PENDAhULUAN}

Pembelajaran bahasa dapat berupa masukan dari pengajar, dari buku ajar ataupun materi ajar, dan dari pemelajar lain yang berinteraksi di kelas bahasa. Pengajar dan pemelajar lain di kelas bahasa berperan sebagai sarana untuk interaksi, sedangkan buku dan materi ajar berperan sebagai sumber belajar. Oleh sebab itu, tujuan dari pembelajaran bahasa adalah menyediakan sumber pembelajaran berupa contoh bahasa yang sesuai dengan pemelajar sebagai masukan terbaik dalam proses pembelajaran bahasa (Cook: 2016). Stephen Krashen yang terkenal dengan teorinya yang kontroversi mengenai "Hipotesis Masukan" menyatakan bahwa, masukan yang bisa dipahami adalah "satu-satunya alasan bagi pemerolehan bahasa kedua" (Brown: 2007). Ini berarti, seorang pengajar harus memiliki kesadaran akan pemilihan materi ajar yang cocok dengan pemelajarnya. Penyesuaian materi dengan kemampuan pemelajar akan memberikan efek yang baik kepada pembelajaran sehingga nantinya pemelajar dapat membaca, mendengar, menulis, dan berbicara sesuai dengan harapan pengajar.

Teks yang terdapat dalam buku ajar harusnya sesuai dengan tingkatan pemelajar yang dituju. Keluhan terhadap teks yang sulit dibaca dan dipahami sering dilontarkan oleh para pemelajar tentang buku pelajaran yang mereka gunakan. Harmer (2007) menyatakan bahwa masalah dalam buku ajar untuk pemelajar adalah terdapatnya topik yang cukup kompleks dan ketidaksesuaian bahasa yang digunakan dengan level kemampuan pemelajar sehingga sulit sekali untuk membuat pemelajar paham terhadap materi pelajaran. Selain itu, teks yang sulit dibaca tentu saja mengurangi motivasi belajar pemelajar karena mereka sudah menyerah terlebih dahulu sebelum memulai pelajaran. Para ahli pendidikan menemukan bahwa pemelajar belajar membaca secara bertingkat, dan pembelajaran terbaik mereka ketika mereka diberikan materi yang ditulis sesuai dengan level bacaan mereka (DuBay: 2004).

Pengajar sebagai pengguna buku diharapkan menyadari pentingnya keterbacaan sebuah teks sehingga melakukan evaluasi terlebih dahulu sebelum menggunakan teks yang disediakan dalam buku ajar. Pemilihan teks yang tepat akan efektif bagi pengajaran dan pemilihan teks yang cermat dalam buku ajar akan memberikan masukan yang baik kepada pemelajar sehingga mereka dapat memproduksi bahasa yang diinginkan.

\section{LANDASAN TEORI}

Readability berasal dari kata 'read' dan 'ability' yang berarti mampu atau sanggup untuk dibaca. Readability atau keterbacaan teks menyatakan bahwa teks tersebut menarik dan mudah dibaca sehingga 
pembaca teks tidak membutuhkan banyak waktu dan usaha untuk memahaminya. DuBay (2004) menuliskan beberapa pendapat ahli mengenai keterbacaan teks yaitu, Edgar Dale dan Jeanne Chall (1949) menyatakan keterbacaan teks sebagai kemudahan secara menyeluruh tentang elemen-elemen yang ada dalam teks bacaan yang mempengaruhi kesuksesan pembaca dalam memahami, membaca dengan cepat, dan menemukan bahwa teks itu menarik bagi mereka. Goerge Klare (1963) mendefinisikan keterbacaan teks sebagai pemudahan pengertian dan pemahaman terhadap cara sebuah teks ditulis. G. Harry McLaughlin (1969) mendeskripsikan keterbacaan teks sebagai tingkatan kemudahan membaca dan memahami ketika suatu teks diberikan kepada sekelompok orang. Adapun Gretchen Hargis (1998) menyatakan keterbacaan teks sebagai kemudahan membaca kata dan kalimat.

Tujuan awal dari tes tingkat keterbacaan teks adalah untuk mengembangkan metode yang praktis untuk mencocokkan antara teks bacaan dan kemampuan pemelajar. Hal ini dilakukan untuk memudahkan pengajar, penulis, dan penerbit dalam menentukan tingkat keterbacaan teks bagi pemelajar yang dituju. Penelitian awal mengenai keterbacaan teks dilakukan oleh L.A. Sherman pada tahun 1880, profesor sastra Inggris di Universitas Nebraska. Ia membandingkan antara teks sastra kuno dengan sastra modern. Ia menemukan fakta tentang faktor yang menyebabkan para pemelajarnya sulit untuk memahami sastra kuno dibandingkan dengan sastra modern. Faktor tersebut adalah banyaknya kosakata dalam satu kalimat. Zaman pra-Elizabeth ditemukan rata-rata terdapat lima puluh kata dalam satu kalimat, zaman Elizabeth ada empat puluh lima kata, zaman viktorian ada dua puluh sembilan kata, dan pada zaman modern hanya duapuluh kata per kalimat.

Kemudian ditahun 1921, Edward L. Thorndike seorang spikolog dari universitas Kolombia, mencatat bahwa pengajar bahasa di German dan Rusia menggunakan perhitungan kosakata untuk mencocokkan teks dengan pemelajar mereka. Semakin banyak kosakata yang sering dipakai digunakan dalam teks, semakin mudahlah teks tersebut untuk dibaca. Kemudian beliau menulis buku Teacher's Word Book yang berisikan daftar kosakata-kosakata bahasa Inggris yang paling sering digunakan. Daftar kosakata ini banyak membantu ahli pendidikan, penerbit buku, dan pengajar untuk mengevaluasi teks yang akan digunakan untuk pembelajaran. Berdasarkan penelitian Thordike ini, kemudian muncullah banyak penelitian lanjutan mengenai keterbacaan teks. Penelitian-penelitian ini kemudian menghasilkan formula keterbacaan teks yang mudah diaplikasikan dan bahkan dengan berkembangnya teknologi dapat digunakan dengan memakai program komputer tertentu.

Salah satu formula keterbacaan yang populer diantaranya adalah Formula Flesch yang dikembangkan oleh Rudolf Flesch (Stephen: 2000; DuBay: 2004). Formula ini memberikan skala 0 (untuk teks paling sulit dibaca) hingga 100 (untuk teks yang paling mudah dibaca). Formula ini dihitung berdasarkan panjang kalimat dan jumlah silabel per-kata. Rumus yang digunakan adalah:

Score $=206.835-(1.015 X$ ASL $)-(84,6$ X ASW $)$

ASL: Average sentence length (rata-rata jumlah kata dalam satu kalimat)

ASW: Average number of syllables per word (rata-rata jumlah silabel dalam satu kata)

Hasil skor dari formula Flesch akan menentukan tingkatan keterbacaan teks, yaitu:

\begin{tabular}{|c|c|c|}
\hline Reading Ease Score & Style Description & Estimated Reading Grade \\
\hline 0 to 30 & Very difficult & College graduate \\
\hline 30 to 40 & Difficult & $13^{\text {th }}$ to $16^{\text {th }}$ grade \\
\hline 50 to 60 & Fairly difficult & $10^{\text {th }}$ to $12^{\text {th }}$ grade \\
\hline 60 to 70 & Standard & $8^{\text {th }}$ and $9^{\text {th }}$ grade \\
\hline 70 to 80 & Fairly easy & $7^{\text {th }}$ grade \\
\hline 80 to 90 & Easy & $6^{\text {th }}$ grade \\
\hline 90 to 100 & Very easy & $5^{\text {th }}$ grade \\
\hline
\end{tabular}

\section{METODE PENELITIAN}

Metode yang dipakai dalam penelitian ini adalah metode kualitatif dengan pendekatan analisis deskriptif. Data penelitian adalah teks-teks bacaan yang terdapat dalam buku pelajaran bahasa Inggris Sekolah Menengah Tingkat Pertama yang berjudul English in Fokus grade VII, VIII, XI terbitan Pusat Perbukuan Departemen Pendidikan Nasional. Dalam setiap buku terdapat bab-bab yang terdiri sub bab listening, speaking, reading, writing, learning essensial, dan learning review. Teks yang dianalisis dalam penelitian ini adalah teks yang terdapat dalam sub bab reading saja.

Analisis data dilakukan dengan tahapan sebagai berikut;

1) Memilih sampel teks.

2) Menghitung jumlah kata dan kalimat dalam sampel.

3) Jika teks cukup panjang akan disederhanakan menjadi 100 kata.

4) Melakukan analisis reading level dengan menggunakan Formula Flesch.

5) Data dipaparkan dalam bentuk tabel dan dideskripsikan sesuai dengan kebutuhan. 


\section{HASIL DAN PEMBAHASAN}

Tabel Berikut ini memuat hasil tingkat keterbacaan teks dengan Formula Flesch pada buku English in Fokus Grade VII,

Tabel 1. Analisis keterbacaan teks dalam buku English in Fokus Grade VII

\begin{tabular}{|c|c|c|c|c|c|c|}
\hline Teks & Halaman & Jumlah Kata & $\begin{array}{c}\text { Jumlah } \\
\text { Kalimat }\end{array}$ & Skor & Reading level & $\begin{array}{c}\text { Estimated } \\
\text { Reading } \\
\text { Grade }\end{array}$ \\
\hline 1 & 12 & 82 & 13 & 79,1 & $\begin{array}{l}\text { Fairly easy to } \\
\text { read }\end{array}$ & $7^{\text {th }}$ grade \\
\hline 2 & 30 & 100 & 10 & 79,1 & $\begin{array}{c}\text { Fairly easy to } \\
\text { read }\end{array}$ & $7^{\text {th }}$ grade \\
\hline 3 & 51 & 71 & 6 & 74,7 & $\begin{array}{c}\text { Fairly easy to } \\
\text { read }\end{array}$ & $7^{\text {th }}$ grade \\
\hline 4 & 94 & 78 & 10 & 74,7 & $\begin{array}{c}\text { Fairly easy to } \\
\text { read }\end{array}$ & $7^{\text {th }}$ grade \\
\hline 5 & 113 & 95 & 8 & 69,8 & $\begin{array}{c}\text { Fairly easy to } \\
\text { read }\end{array}$ & $7^{\text {th }}$ grade \\
\hline 6 & 132 & 80 & 8 & 69,8 & $\begin{array}{l}\text { Fairly easy to } \\
\text { read }\end{array}$ & $7^{\text {th }}$ grade \\
\hline
\end{tabular}

Berdasarkan hasil analisis teks pada tabel diatas, terlihat bahwa teks dalam buku ajar English in Fokus Grade VII sudah sesuai dengan level bacaan siswa kelas VII. Jumlah kata dan jumlah kalimat juga tidak panjang sehingga siswa dapat dengan mudah memahami bacaan. Jika ditelisik lebih dalam, pada teks yang menjadi sampel data, umumnya kalimat terdiri dari kalimat sederhana (simple sentence) yang terdiri dari 1 klausa. Terdapat 55 kalimat dari sampel data, dan hanya ditemukan 8 kalimat Majemuk (complex sentences), yaitu sebagai berikut;

1.Pada teks ke 3 berjudul "Dream Food Restaurant"

"You should try its oxtail soup and dorayaki cake, the taste are so delicious"

"it also gives discount for students, just show your students' ID when you pay at the cashier"

2.Pada teks ke 4

"The place that we often visit is Bali"

"the restaurant face directly to the beach so that the people in the restaurant can see the sunset."

3.Pada teks ke 5 berjudul "Mr. Kartolo, the Farmer"

"Rice fields become fresh and green during this season and by the end of this season Mr. Kartolo is ready to harvest his corps.

"Milking the cows, feeding the livestock, and cleaning the barns are among Mr. Kartolo's duties before breakfast"

4.Pada teks 6 berjudul "Keeping Fit"

"First of all, she joins health club where she usually exercises after work"

"Finally, Wati sometimes consumes multivitamins to supply energy because she is very busy woman."

Jika dilihat dari gradasi tingkat kesulitan teks, teks-teks sampel pada English in Fokus grade VII, memiliki tingkat kesulitan teks yang bertahap. Topik bacaan yang dibahas juga merupakan topik sehari-hari sehingga siswa memiliki wacana terhadap teks tersebut. Menurut Winarto Surakhmand dalam Mulyadi (2011), "informasi yang terdapat dalam bacaaan tersebut dapat dengan mudah dipahami apabila pembaca memiliki apersepsi (pengetahuan awal) yang cukup terhadap bahan yang sedang dibaca."

Berikut ini hasil analisis keterbacaan teks dari buku English in Fokus grade VIII,

Tabel 2. Analisis keterbacaan teks dalam buku English in Fokus Grade VIII

\begin{tabular}{|c|c|c|c|c|c|c|}
\hline Teks & Halaman & Jumlah Kata & $\begin{array}{c}\text { Jumlah } \\
\text { Kalimat }\end{array}$ & Skor & Reading level & $\begin{array}{c}\text { Estimated } \\
\text { Reading } \\
\text { Grade }\end{array}$ \\
\hline 1 & 16 & 144 & 10 & 83,1 & Easy to read & $6^{\text {th }}$ grade \\
\hline 2 & 39 & 169 & 13 & 68,3 & Standard & $8^{\text {th }}-9^{\text {th }}$ grade \\
\hline 3 & 40 & 152 & 8 & 54,7 & $\begin{array}{c}\text { Fairly difficult } \\
\text { to read }\end{array}$ & $\begin{array}{c}10^{\text {th }}-11^{\text {th }} \\
\text { grade }\end{array}$ \\
\hline 4 & 60 & 153 & 14 & 66,9 & Standard & $8^{\text {th }}-9^{\text {th }}$ grade \\
\hline 5 & 62 & 212 & 19 & 83,8 & Easy to read & $6^{\text {th }}$ grade \\
\hline
\end{tabular}




\begin{tabular}{|c|c|c|c|c|c|c|}
\hline 6 & 92 & 290 & 17 & 76,4 & $\begin{array}{c}\text { Fairly easy to } \\
\text { read }\end{array}$ & $7^{\text {th }}$ grade \\
\hline 7 & 115 & 227 & 19 & 63,1 & Standard & $8^{\text {th }}-9^{\text {th }}$ grade \\
\hline 8 & 135 & 212 & 15 & 85,6 & Easy to read & $6^{\text {th }}$ grade \\
\hline
\end{tabular}

Dari tabel terlihat bahwa hanya teks sampel ke 2, 4, dan 7 dari 8 sampel yang sesuai tingkatannya dengan siswa kelas VIII. Teks 1, 5, 6 dan 8 dianggap mudah dan cukup mudah. Sedangkan teks ke 3 dianggap cukup sulit. Jika ditelaah lebih dalam, teks ke 3 dalam sampel analisis ini, memiliki terlalu banyak kalimat majemuk dan kosakata sulit. Topik yang dibahas juga cukup sulit bagi siswa kelas VIII yang tidak akrab dengan geografis daerah Nusa Tenggara.

Teks ini terdiri dari 152 kata, tetapi hanya dalam 8 kalimat. Beberapa kalimat majemuk bertingkat cukup sulit difahami oleh siswa kelas VIII, seperti;

1. "The long northern arch of the island chain is the results of volcanic activity, whilst the southern islands are formed from coral deposits."

2. "Most of the eastern islands are arid, due to hot winds blowing from the continent of Australia and sparsely vegetated."

3. "The northern part of the chain is known for deep lakes contained in the craters of extinct volcanoes, the most famous of which are the coloured mineral lakes on Gunung Keli Mutu in Flores."

Jika pengajar ingin menggunakan teks ini dalam pengajaran, siswa harus diberikan pengayaan kosakata baru dan menjelaskan mengenai geografis Nusa Tenggara sebelum memberikan teks tersebut kepada siswa.

Tabel berikut menjabarkan tentang analisis keterbacaan teks dalam English in Fokus Grade IX,

Tabel 3. Analisis keterbacaan teks dalam buku English in Fokus Grade IX

\begin{tabular}{|c|c|c|c|c|c|c|}
\hline Teks & Halaman & Jumlah Kata & $\begin{array}{c}\text { Jumlah } \\
\text { Kalimat }\end{array}$ & Skor & Reading level & $\begin{array}{c}\text { Estimated } \\
\text { Reading Grade }\end{array}$ \\
\hline 1 & 14 & 143 & 10 & 93 & $\begin{array}{c}\text { Very easy to } \\
\text { read }\end{array}$ & $5^{\text {th }}$ grade \\
\hline 2 & 35 & 150 & 10 & 71,5 & $\begin{array}{c}\text { Fairly easy to } \\
\text { read }\end{array}$ & $7^{\text {th }}$ grade \\
\hline 3 & 39 & 129 & 8 & 38,7 & Difficult to read & College \\
\hline 4 & 42 & 126 & 7 & 43,5 & Difficult to read & College \\
\hline 5 & 58 & 113 & 6 & 84,4 & Easy to read & $6^{\text {th }}$ grade \\
\hline 6 & 60 & 104 & 9 & 84,4 & Easy to read & $6^{\text {th }}$ grade \\
\hline 7 & 88 & 225 & 12 & 70,5 & Fairly easy to & $7^{\text {th }}$ grade \\
\hline 8 & 91 & 245 & 16 & 77,4 & $\begin{array}{c}\text { Fairly easy to } \\
\text { read }\end{array}$ & $7^{\text {th }}$ grade \\
\hline 9 & 114 & 184 & 14 & 74 & Fairly easy to \\
read & $7^{\text {th }}$ grade \\
\hline 10 & 117 & 169 & 13 & 63 & Standard & $8^{\text {th }}-9^{\text {th }}$ grade \\
\hline
\end{tabular}

Dari tabel dapat dilihat hanya 1 teks dalam buku English in Fokus Grade IX yang sesuai dengan siswa kelas IX. 7 teks sangat mudah dan cukup mudah dan 2 teks sulit bagi siswa kelas IX. 7 teks yang dianggap mudah bagi siswa kelas IX karena 3 teks diantaranya (sampel teks ke 1, 5, dan 6) merupakan teks prosedur yang dituliskan dalam bentuk intruksi dan dijelaskan satu persatu dengan kalimat-kalimat sederhana. Sisanya 4 teks lainnya merupakan teks narasi yang dituliskan dengan alur yang jelas.

2 teks dari teks sampel dalam buku ini dianggap sulit karena beberapa hal,

1. Topik yang dibahas tidak akrab dengan siswa kelas IX.

2. Banyaknya kalimat majemuk yang digunakan dalam teks seperti;

a. "Chinese culture played a truly significant role in the development of visual art in Indonesia although not as strong as the Hindu, Buddhist or Muslim influences."

b. "In Gianyar Bali, strong links between the Chinese and local people are evidenced by the Chinese-style roofing on the palace that was rebuilt at the end of the last century."

c. "The developing of wood in Indonesia from earliest times, provided the people with the raw materials to produce functional and artistic artefacts."

d. "Climatic condition problem have eliminated some remain of wooden artefacts from a very early date, it's not leaving many evidence, but it seemed the woodcarving was an early form of artistic expression." 
e. "So, we have known now that woodcarving is an old art and keep developing into many form and designs."

Dari analisis ini terlihat bahwa rata-rata teks sampel buku English in Fokus Grade IX terlalu mudah bagi siswa kelas IX. Jika pengajar menggunakan teks ini dalam pengajaran, disarankan untuk menambah bahan bacaan setara kemampuan kelas IX sehingga siswa tidak cepat bosan dalam pembelajaran. Untuk teks yang terlalu sulit bagi siswa, pengajar dapat mengganti teks dengan topik yang sama atau membahas teks ini bersama-sama siswa sehingga jika ada hal yang tidak difahami dapat segera dijelaskan kepada mereka.

\section{SIMPULAN DAN SARAN}

Analisis keterbacaan teks memperlihatkan bahwa hanya buku English in Fokus Grade VII yang sesuai tingkat keterbacaannya dengan pemelajar kelas VII, sedangkan buku English in Fokus Grade VIII dan IX dianggap tidak sesuai dengan pemelajarnya. Pada buku English in Fokus Grade VIII, hanya 3 teks yang sesuai dengan tingkat pemelajar dari 8 teks yang dianalisis. Sisanya dianggap terlalu mudah dan terdapat 1 teks yang terlalu sulit. Hanya 1 teks pada buku English in Fokus Grade IX yang sesuai dengan tingkat pemelajarnya dari 10 teks yang dianalisis. 8 teks dianggap terlalu mudah dan 1 teks dianggap terlalu sulit. Dari hasil ini dapat disimpulkan bahwa buku English in Fokus Grade VIII dan IX terlalu mudah bagi tingkatan pemelajarnya.

Hasil analisis keterbacaan teks memperlihatkan bahwa untuk menentukan keterbacaan teks dibutuhkan beberapa hal penting yaitu,

1. Jumlah kata sulit dalam kalimat.

2. Jenis kalimat yang digunakan dalam teks.

3. Topik bacaan yang dibahas dalam teks disesuaikan dengan apersepsi pembacanya.

Oleh sebab itu diperlukan ketelitian dari pengajar untuk menentukan teks yang setara dengan kemampuan siswanya. Sedangkan bagi penulis buku, diharapkan memiliki pengetahuan tentang analisis keterbacaan teks sehingga lebih selektif dalam memilih teks untuk buku ajar yang ditulis.

\section{DAFTAR PUSTAKA}

Brown, Douglas H. (2007). Prinsip Pembelajaran dan Pengajaran Bahasa (5 ${ }^{\text {th }}$ Ed.). Jakarta: Pearson Education, Inc.

Cook, Vivian. (2016). Second Language Learning and Language Teaching ( $5^{\text {rd }}$ Ed.). New York: Routledge.

DuBay, William H. (2004). The Principles of Readability. Costa Mesa: Impact Information.

Harmer, Jeremy. (2007). The Practice of English Language Teaching (4 ${ }^{\text {th }}$ Ed.). Edinburgh: Person Longman.

Nunan, D \& Bailey, K.M. (2009). Exploring Second Language Classroom Research. Boston: Heinle Cengage Learning.

Mulyadi. (2011). Tingkat Keterbacaan Reading Materials dalam Mata Kuliah Telaah Teks Bahasa Inggris STAIN Pamekasan. Nuansa. Vol.8 No.2. 225 - 238.

Mendiknas. (2008). Panduan Pengembangan Bahan Ajar. Jakarta: Depdiknas.

Peraturan Menteri Pendidikan dan Kebudayaan Republik Indonesia Nomor 71 Tahun 2013. (2013). Buku teks Pelajaran dan Buku Panduan Guru untuk Pendidikan Dasar dan Menengah. http://repository.unand.ac.id.

Saroni, dkk. (2017). Analisis Keterbacaan Teks pada Buku Tematik Terpadu Kelas V SD Berdasarkan Grafik Fry. Prosiding Seminar Nasional KSDP Prodi S1 PGSD "Konstelasi Pendidikan dan Kebudayaan Indonesia di Era Globalisasi. 157- 164.

Stephens, Cheryl. (2000). All About Readability. http://plainlanguage.com/newreadability.html. Ur, Penny. 1991. A Course in Language Teaching. Cambridge: Cambridge University Press. 